\title{
The Competence of Hellas on Search and Rescue Items in the Aegean Area
}

\author{
Korontzis Tryfon \\ Social and Political Sciences of Athens, Panteion University \\ P.Ralli 228, 18454, Nikaia, Piraeus, Greece \\ E-mail: tmkoront@otenet.gr
}

$\begin{array}{lcc}\text { Received: February 7, } 2012 & \text { Accepted: March 14, } 2012 & \text { Published: June 1, } 2012 \\ \text { doi:10.5539/res.v4n2p89 } & \text { URL: http://dx.doi.org/10.5539/res.v4n2p89 }\end{array}$

\begin{abstract}
Hellas as a maritime State with a long tradition in shipping and allocating one of the most powerful fleet in the world, played and still plays important and fundamental role in the international conferences, for the establishment of international regulations and conventions on subjects of maritime safety in which is included Search and Rescue (SAR). Parallel with the international legal framework which is applied by Hellas, was also developed and national legal framework which is consent to the orders of the international law and aims in the most effective providing, application and co-ordination of SAR services in regions where base on the international law, Hellas has institutional competence. At the same time Hellas, respectively participated in all the international conferences for the establishment of international conventions and regulations that concerned subjects of air transports, as well as providing services of air SAR, constituting and in this case national framework which is consent to the orders of the international law and aims in the most effective providing, application and co-ordination of SAR services in regions where base on the international law, Hellas has institutional competence.
\end{abstract}

Keywords: Search and Rescue (SAR), Hellas, Turkey, Hellenic Coast Guard (HCG), Aegean Sea, Hellenic Joint Rescue Coordination Center (JRCC), Flight Information Region (FIR), Turkish Coast Guard Command (TCGC)

\section{Introduction}

The enormous and rapidly growth of the shipping and the air transports which developed and still is developing because the high development of technology from the second half of the last century until now, led automatically to the need of SAR services growth (Note 1). These services suitably organized and staffed with specialized executives and provided with suitable means, aim in the disposal of effective SAR services in all the air and marine regions of the world.

According to the international texts which have been incorporated in the national legal order as "search", is determined an operation, usually coordinated from a SAR centre or sub-centre, that uses sufficient personnel and means for localization of individuals who are in danger, while as "rescue" is determined as an operation for rescue of individuals who are in danger and which provides initially to them medical or other cares and transporting them in sure area.

As "SAR service" is determined the operation of danger watching the communication, the co-ordination and the processes of SAR services including also the provisions for medical advices, medical help or medical landing, with the use of public and private means, involving collaborating aircrafts, vessels and other ships as well as installations.

The SAR services are providing in a region with determined dimensions, which is connected with a SAR centre, inside of which are provided of SAR services (Note 2). As centre of co-ordination rescue is determined a unit, responsible for the growth of effective organization of SAR services as also for the co-ordination of conducting SAR operations inside the SAR region. 
Regarding the Hellenic region of SAR responsibility as it will be shown below, coincides absolutely with the limits of region of Athens FIR (Flight Information Region), in which except the control of air trafficking, Hellas is responsible to execute air and maritime SAR (Note 3).

SAR in the space of Aegean Sea occupies in daily bases the political but also military leaderships of three Ministries in Hellas (Ministry of Foreign Affairs, National Defense, Citizen Protection/ General Secretariat of Safety Navigation/ Hellenic Coast Guard Headquarters, because the incidents that continuously take place in the Aegean Sea, cause continuous "frictions" in the Hellenic-Turkish relations since the jurisdiction of Hellas in the FIR Athens is disputed by Turkey.

Besides during the application of operational procedures at the duration of SAR (Note 4) in order to be materialized national planning's (Note 5) for localization and rescue of persons in the area of Aegean Sea, it may be caused incident of high danger or even crisis (Note 6). Characteristically is reported the rescue of Turkish pilot afterwards the conflict with the aircraft of the Hellenic pilot, named Iliadi on 23 May 2006 (Note 7), the stranding of Turkish M/V in the Hellenic island Kos, little time before the crisis of Ymia in January 1996 and the contestation of the Hellenic jurisdiction from the Turkish captain for providing SAR services by Hellas (Note 8), the formulation of "Behavior Code" by Turkey in order to be avoided intensities in the space of Aegean Sea etc (Note 9).

It is marked that Hellas recognizes officially as only legal difference with Turkey the delimitation of condimental shelf (Note 10). By information of secondary sources, are taking part for a long time now negotiations between Hellas and Turkey without the object of these to be known (Note 11).

Aim of the present concise study is to examine the competence of Hellas SAR in the Aegean Sea, having base the existing international and internal legal framework, focusing in the points according to which was assigned in Hellas the service of competence of SAR in the FIR Athens, the services of SAR that Hellas provides in the space of Aegean Sea, the new systems that have been developed for the control of maritime trafficking which contribute at the safety of human life in the sea, the contestations of Turkey in the competences that are enforced by Hellas on SAR issues in Athens FIR, problems which are created from these controversies, while the study will be completed with the apposition of conclusions.

\section{SAR Legal Framework}

Specifically on SAR issues are reported the below International Conventions and National Provisions, in which between the other are describing with clarity the obligations for providing help from captains of vessels, skippers or operators of aircrafts in crews or passengers or aircrafts or individuals who are in danger:

\subsection{International legal framework}

(1) Article 11 of Law 3886/1911 (A'224).

(2)Article 25 of Law 211/1947 (A'35) (Note 12).

(3)The International Convention (Safety of Life at Sea: SOLAS) that ratified by the Law 1045/1980 (A' 95) and was modified by the Presidential Degree (PD) 199/2005 (A' 239) and PD 137/2007 (A' 174).

(4) The article 98 of the International Convention UNCLOS 1982, which was incorporated by the Law 2321/1995 (A'136).

(5) The article 10 of the International Convention of Salvage 1989, which was incorporated by the Law 2391/1996 (A' 55).

(6) Hamburg Convention of 1979 (Note 13), which was incorporated by the Law 1844/1989 (A' 100) and was modified by the PD 201/2000 (A'181).

(9) The PD 349/2001 (A' 235).

(10) The Ministerial Decision (MD) with No. 3239.10/01/03 (A' 1900).

(11) The PD 49/2005 (A' 66).

(12) The directive 2009/17/European Parliament and Council, dated on 23 April 2009 on modification of directive 2002/59/EP on the creation of Community system of follow-up of vessels trafficking and informing (Note 14).

\subsection{National legal framework}

(1) PD 6-9-1931, "Determination of territorial sea breaths, regarding items of aviation and its police", (A'325) (Note 15). 
(2) CL (Compulsory Law) 230/1936 (A' 450), "Determination of territorial zone in Hellas» (Note 16).

(3) CL 2597/1940 (A'335), "Movement of planes over the Hellenic Territory".

(4) Article 240 Code of Private Maritime Law [Law 3816/1958 (A'32)].

(5) RD (Royal Decree), 170/1969 (A' 50), "Rules of Air Trafficking".

(6) Articles 210, 224 and 227 of the Public Maritime Code Law [LD (Law Decree 187/73 (A' 61)].

(7) Articles 123, 124 and 175 of Law 1815/1988 (A' 250), "Ratification of Air Code".

(8) Joint Ministerial Decision (JMD) No. 1432.52/93/26.7.93, issued by the Ministers of national Defense and Mercantile Marine "Regulation of Organization and Operation of JRCC", (A' 647).

(9) Articles 97,115 and 122, Law 2287/1995 (A' 20), "Ratification of Military Penal Code".

(10) JMD No. 3221.4/07/05, issued by the Ministers of National Defense and Mercantile Maritime "Modification of Regulation of Organization and Operation of JRCC".

(11) Articles 288 and 307 of the Hellenic Penal Code which are reported "in the obstruction of dissuasion of common danger and omission of owed help" and "omission of deliverance from danger of life" respectively.

\section{SAR Services in the Aegean Sea}

\subsection{Air SAR}

\subsubsection{Generally}

The convention of Chicago 1944 which was ratified by the Law 211/1947 (Note 17), their amendments and the two additives in this Convention which were ratified respectively by the Laws 210/1947 and 211/1947, contain the basic legal framework for the international air space and for the growth of international communications with networks of air connections.

The air space, national and international has been divided in nine (09) [air navigation] (Note 18), regions every one of which includes FIRs (Note 19). The management of them mainly for the control of air trafficking has been assigned in the jurisdiction of neighboring to each FIR States, which the competent authorities of them have the responsibility for the safety of political and military aircrafts air trafficking. The segmentation of the air space in air navigations regions and the delimitation of these belong to ICAO responsibility and is taking place with binding decision by the Council of the Organization from the air navigation Committee (Note 20) and the Secretariat of the Organization in question. The delimitation becomes, based on technical and functional criteria, so that be ensured the bigger effectiveness during the enforcement of air trafficking controlling (Note 21). The international regulations in combination regarding the providing of air trafficking services, with the corresponding national regulations, regulate the handling and the controlling of air trafficking in the national and international space.

All the national, aeronautical laws and regulations must be in harmony with the provisions of Chicago Convention and with the aeronautical Regulations that ICAO publishes with the form of annexes (Note 22).

According to Annex 11 (Annex 11, Chapter 1, Definitions), as FIR is determined an air region of specific extent, in which are provided services of air trafficking and SAR services. The State of responsibility in the particular region, provides all services of air trafficking. In a region of FIR, is enforced control of air trafficking with objective aim the surly and regularly distribution of flights, services of providing flights information as well as SAR for aircrafts that are in dangerous (Annex 11, 2.3.).

It must be noted that the air space of FIR region is distinguished by the air national space of the State. More specifically in State national air space, the State enforce sovereignty while in the air space of its responsibility (FIR) enforces limited jurisdictions that are determined specifically by the international law and the Convention of Chicago, with exception the section of FIR region that coincides with national air space. FIR that includes section of international air space is not considered as sovereign national space. Remains international space which is not granted and which simply the management is undertaken by each State of responsibility in order to enforce the control and the co-ordination of air trafficking.

\subsubsection{Determination of competent FIR authority}

According to the definitions of Chapters 1, Annexes 2 and 11 of Chicago Convention, ATS (Air Traffic Service) is the adequate "Authority", which is indicated by the State and is charged with the providing of air trafficking services in "specific air space". The air space can be national air space or section of international air space or space of undefined national sovereignty which belongs in a region of FIR. Responsible ATS is determined: 
a. - for the national space from the State that enforces sovereignty,

b. - for the section of the international air space inside of FIR region from the State that accepted the establishment and the providing of ATS services inside the FIR region of its jurisdiction.

More specifically from the competent authority is enforced the control of air trafficking (for instance flight plans, stains of flight and others), are provided according to the international law and the conventions all the forecasted aeronautical information for the flight, as well as the SAR of aircrafts in the particular region.

Unique Authority of Athens FIR (FIR Athinai), is Air Traffic Control Center (ATCC) and is the Hellenic Service of Civil Aviation (YPA) (Note 23) with land centre of region control the international Airport of Athens "Eleytherios Venizelos".

\subsubsection{Competences of competent FIR authority on SAR issues}

The competences of the competent FIR authority consist the followings:

a. - control of air trafficking,

b. - providing of SAR services,

c. - provisional cession of air space and

d. - recognition - deterrence of aircrafts.

More specifically the international and national legislation for SAR on air accidents forecast the following:

i) Article 25 of Chicago Convention (Law 211/1947) titled "Aircraft in distress" which determines:

"Each contracting State undertakes to provide such measures of assistance to aircraft in distress in its territory as it may find practicable, and tom permit, subject to control by its on authorities, the owners of the aircraft or authorities of the State in which the aircraft is registered to provide such measures of assistance as may be necessitated by the circumstances. Each contracting State, when undertaking search for missing aircraft, will collaborate in coordinated measures which may be recommended from time to time pursuant to this convention".

The provision of the above article should be marked that it is reported only in the obligation of providing SAR services in regions of responsibility that cover only national air space.

ii) With Annex 12 of Chicago Convention (Note 24), in cases of aircrafts accidents, the obligation of SAR extended beyond national and in the international air space as well as in the open sea.

More specifically in the Annex in question are included regulations - rules of standardization and recommended practices that forecast the process of SAR operation in cases of aircrafts accidents, the determination of areas of responsibility (Annex 12,2) as well as the collaboration between the competent services (Annex 12, 3.1, 3.2).

As SAR region according to the Chapter 1 Annex 12, is determined a region with determined dimensions, connected with a co-ordination and rescue centre, in which are provided SAR services. They are regions of responsibility of each State the limits of which are determined according to the provisions of Chapter 2 of Annex 12.

The limits of SAR regions are determined with proportional process like the one that is forecasted for the determination of FIRs limits. Thus the obligation of benefit of SAR services that is forecasted by the article 25 of Chicago Convention, is extended beyond the national air space and in the international air space and the open sea and the responsibility in these regions is assigned in a contracting individually State (Annex 12, 2.1.1.1). The limits of regions of the competent State for SAR services, for aircrafts in distress in sections of international air space as well as above the open sea, are determined with Periodical Air Navigations Agreements which are approved by the Council of ICAO.

It is noted that these limits are usually determined in a way that they coincide with the limits of FIRs Regions (Annex 12, Chapter 2, Recommendation 2.2.1.1) and that the assignment of responsibility of providing services in an international air space section, does not mean in any case recognition of extension of sovereignty.

The limits of SAR regions until November 2004, before being in force the modification of Annex 12, was recognized according to the Chapter 2 of the Annex that determination of SAR regions became based on the borders of States. Afterwards the modification of Annex 12 is henceforth determined with clarity that the determination of SAR regions becomes not based on the borders, but according to the technical and operational capabilities of states.

iii) The Periodical Air navigations Plans and the guidelines directives and regulations of ICAO for SAR (Search and Rescue Manual, ICAO, Doc, 7333). 
iv) Articles 123 and 124 of Law 1815/1988 (A' 250) "Ratification of Air Code Law", in which are determined respectively that " 1 . the captain of the aircraft in flight or ready for taking off is compelled to provide aid in person that is in danger in the sea or in a region that is not served with other rescue means, if it is possible without the danger of the aircraft, crew or the passengers", "everyone that conceives aircrafts that has been abandoned or its ruins is compelled to announce it without delay in the local air authority, or if does not exist such authority in the nearest police authority".

vi) Article 122 of Law 2287/1995 (A' 20), "Ratification of Military Penal Code", in which it is determined that "Head, captain of a ship or of aircraft or operator of an aircraft, who without legitimate cause or opposite order, omits to provide help in military unit or in any aircraft or vessel that is in distress, is punished with imprisonment up to ten years"

v) The handbook of NATO/ATP-10 (D) in which are described the obligations of each member State of NATO in providing SAR services in NATO forces.

vi) Handbook IAMSAR Manual (Aeronautical \& Maritime SAR Manual) (Note 25)

\subsubsection{Determination of Athens FIR}

The regulations for the delimitation of FIRs of Air navigation Region in Europe, took place in the frames of third (Paris 1952) and fourth (Geneva 1958) Periodical Air navigations Conferences of Europe, which their "recommendations" and the Periodical Air navigations Agreements containing in them, related to FIRs delimitations or to the decompositions of their limits, became acceptable by the Council of ICAO at the meetings held on 23-6-1952 and 15-5-1958 (Note 26).

The delimitation of Athens FIR as well as Istanbul FIR became acceptable by the Council with the recommendation No. 1 (Recommendation No 1/RAC -3) and the containing in this the Periodical Air navigation Agreement, of the Periodical Conference of 1952 and the final arrangement of its limits with partial decomposition based on the recommendation No 9/2 of the Periodical Conference of 1958. The limits of FIR were depicted to the attachment at the third final report (1952)] to the Council map of air navigation of Europe Region No. 7 (Air Navigation Plan - European Region, Chart No 7). The recommendation to the Council were unanimous, consequently was existed also the consent of Turkey. Simultaneously with the same decisions of the Council, were delimited also the regions of SAR responsibility, limits of which coincide with the corresponding limits of FIRs (points 2.2.1 and 11.1 respectively of the reports to the Council 1952 and 1958).

It is noted that as is reported clearly in the point 2.6.2 of the Report to the Council of the fourth Periodical Air navigation of Conference in 1958, at the delimitation and the partial decomposition in 1958 of Athens FIR limits, were taken into consideration without submission of objections on behalf of Turkey the aeronautical maps that published in 1955 (Note 27) and Hellas had notified in ICAO. These maps were covering the Balkans and European Turkey and presented the limits of Hellenic national air space in the $10 \mathrm{~nm}$ (nautical miles) (Note 28).

Based the above, the arrangement of FIR Athens was determined legally according to the forecasted processes and decisions of ICAO, without Turkey formulates reserve or protest. Relevantly it contributed also in its consolidation with the acceptance and its application (Note 29).

Based on the delimitations that became acceptable by the Council of ICAO, the competent authority of FIR Athens, undertook the responsibility of air trafficking control for the flights of political and military aircrafts on national and international air space. All the relative elements are contained in the Handbooks of Aeronautical Information, which obligatorily according to the Annex 15 of the Chicago Convention (Note 30) publishes and observes, inform the Civil Aviation Service (Note 31, 32).

It deserves to be marked that in the Recommendation No 1 to the Council of ICAO (paragraph 2.1 of the Final Report of the Committee of Air Space Rules and Control of Air Trafficking), Turkey in the coordinates that it gave for the delimitation, reported with clarity in the westwards sea borders which coincide absolutely with the corresponding coordinates of Eastern marine borders of Hellas, fact that is also confirmed by the Aeronautical Chart of 2342/1953 of Turkish Civil Aviation Service, which was approved by the ICAO, with the Turkish Handbook of Aeronautical Information, publication 1994 (AIP - Turkey, RAC 3-1-4A) (Note 33).

Athens FIR (map 1 about here) has been engraved based on the Hellenic -Turkish marine borders and tough to the Turkish territorial sea. The Air line of FIRs Athens -Turkey in this marine region, coincides with the marine limit-line of the territorial sea of Hellas and Turkey, apart from two points southern of Evros and southern of Rhodes where the delimitation goes through from sections of open sea (Note 34). The limits of FIR Athens coincide apart from the two points that are created international borders, with the agreed line of limits of territorial sea from the delta of Evros up to Kastelorizo island, engraved regarding Evros with coordinates that 
are forecasted in the Protocol of Athens on 3-11-1926 (Note 35). As far as concern the area of Dodekanisa with coordinates which are punctuated to the two agreements between Turkey and Italy on 4-1-1932 and 28-12-1932 (Note 36).

From Kastelorizo island the limit line of FIR Athens follows south-western direction leading in 34th parallel and afterwards continuing westwards under Crete leads to the 19th meridian, on which changes direction and begins going up north parallel with the FIR of Italy, up to northern utmost in 41st parallel where it meets the land borders of Albania.

It is realized that Istanbul FIR coincides in Aegean with the national air space of Turkey, while the FIR of Athens is extended to Eastern. It covers big regions of international air space in Aegean, southern of Crete and westwards of the Ionian Islands with result the Region of Athens FIR (Note 37) to include strategic international air space.

\section{Maritime SAR}

The subjects for maritime SAR are regulated by the International Convention on Maritime SAR (Note 38). With this convention for first time was established international system for providing and co-coordinating services of marine SAR.

With the particular Convention, is imposed obligation in the contracting States to organize services of SAR for providing help in rescue surviving from maritime accidents (Note 39) and forecast processes of co-ordination with the national authorities, in case where in the SAR operations participate also vessels or aircrafts of third State/s. The subscription includes sections of open sea that adjacent to the territorial sea of coastal state. Afterwards the adoption of the Convention, the Committee of Marine Safety of IMO proposed and it became acceptable from the mentioned before International Organization, the segmentation of oceans and open seas in thirteen big regions of SAR in which the interested parts delimit the regions of SAR.

The convention of Hamburg contrary to Chicago Convention, does not determine the processes and the mechanisms for the determination of SAR regions responsibility, but refers the regulation of this subject in agreement between the interested coastal neighboring countries (paragraph. 2.1.4 of the Annex of the Convention) and this precisely is its weakness point. In paragraph 2.1.5 of the Annex of this Convention, it is determined that "in case that is not achieved agreement on precise dimensions of region of SAR by the interested parts, these parts will overwhelm each effort in order to achieve an agreement with suitable settings with which will be provided everywhere in the region equivalent co-ordination of SAR services".

The delimitation of SAR regions is not related and will not offend the delimitation of any border between the States (paragraph 2.1.7 of Hamburg Convention).

With the revision of Convention in 1998 (was in force by $1^{\text {st }}$ of January 2000), was determined that the contracting parts where is applicable, will ensure the cohesion between their maritime and aeronautical SAR services, which will be delimited with agreement, according to the paragraph 2.1.4 or with the achievement of agreement with suitable settings according to the paragraph 2.1.5 (paragraph 2.1.8 of the Revised Convention). Also according to the paragraph 2.1.3 of the Revised Convention, the parts individually or in collaboration with other States will ensure that sufficient regions of SAR are determined in each marine region according to the paragraphs 2.1.4 and 2.1.5, and the regions should be continued and not overlapping.

Based on IMO and ICAO recommendations which are depicted in the International Handbook of Aeronautics and Marine SAR (IAMSAR Manual) but also according to the international practice, is predetermined the adoption of identical regions for the air and maritime SAR in order these regions to coincide with FIRs (Note 40).

Beyond that the Convention does not determine processes and mechanisms in the frames of IMO - (an important lack according to my opinion) (Note 41) - for the determination of regions responsibility in the open sea of each coastal State, were not taken into consideration during the formation the regulations of Chicago Convention (1944) and more specifically the international aeronautical Regulations in the subjects of SAR in the international space and in the open sea for being in distress aircrafts. It is marked however that in the preamble of the Convention becomes report in Recommendation No. 40 that was adopted by the International Conference on the Safety of Human Life in the Sea 1960, which recognizes the expediency of coordinative energies for the safety up and down of the surface of the sea, between a number of intergovernmental organizations in which is included and ICAO.

Hellas at the signature of Convention, deposited reserve and declared that "the region of SAR that is reported in the paragraphs 2.1.4 and 2.1.5 of the Convention Annex, is the region inside which Hellas has already 
undertaken the responsibility for SAR aims, that has been determined according to the relative Chicago Convention and the periodical Drawings of ICAO, as well as the Regulation 15 of Chapter V of SOLAS 1960. This region that constitutes the most suitable regulation according to the meaning of paragraph 2.1.5 of the Annex of the Convention was announced in the IMO with the document No. the 44/7-1-1975 of the Ministry of Mercantile Marine and in this region Hellas from a long time carries out SAR operations". It is obvious that from legal opinion the above reserve - statement as unilateral action, cannot consider that commits Turkey.

The above attitude of Hellas was the most advisable, as had already preceded the delimitation of SAR region in the international air space and the international water of Aegean sea which was identified with Athens FIR. Also is not legally possible, other State having the responsibility for the air space and section of open sea for being in distress aircrafts and other State the responsibility for the same section of open sea for being in distress vessels. Operationally the regions must be identified in order to exist the most desirable result.

In Hellas the Competent Authority for the application of provisions of Hamburg Convention, is the Hellenic Coast Guard (Note 42).

The maritime and air SAR are provided by the Hellenic Coast Guard and the Air force (Ministry of National Defense) respectively with the subscription and collaboration of other institutions when it is necessary. For this reason and taking into consideration the provisions of Law 1844/1989, was established the Joint Rescue Co-ordination Center (JRCC), by which are coordinated the air and maritime SAR operations.

\section{Hellenic Joint Rescue Co- ordination Center (JRCC)}

The organization of JRCC (Note 43), which is based in the Ministry of Citizen Protection/HCG HQs/Division of Search and Rescue is as follows:

JRCC is separated in two departments:

a. - The maritime department which is charged for each maritime incident. Administratively and operationally is under the supervision of SAR Division/ HCG HQs. It is manned by a superior officer as head of department, three superiors' officers and five more inferior officers in each guard as well as five assistants (petty officers). All these stuff are personnel of HCG have been graduated of specific faculties (Academies of Merchant Shipping) and have previous experience in SAR vessels.

b. - The air department which is charge for each air incident, operationally is under the supervision of the General Staff of Air force/ Operational Center and administratively in the 129 Supported Administration. Head is a Colonel of Air force (with previous experience as pilot), one officer specialized on radio nautical section, four petty officers as responsible of duties and four soldiers. All the personnel of air department should have experience in flying SAR means.

Also in JRCC are posted three officers from Hellenic Navy as contact points in order to be achieved better co-ordination and exchange of information between HCG and Hellenic Navy. The personnel of JRCC processes each incident, analyze it and its particularities and finally it draws up the plan of SAR that will be executed by the suitable units of SAR. The infrastructure, the means that provides and the processes that applies are conditioned by the international conventions and the handbooks of international organizations (ICAO, IMO, NATO) as well as from the regulation of its operation MD 1432.52/93 (B'647) and MD 3221.4/07/05 (B' 702).

JRCC is the Service that has been determined in order to provide effective help in likely accidents. The centre in question is supported regarding the maritime accidents from five (5) Sub SAR center (Rescue Sub-Centers RSCs) that are located at the Port Police Authorities of Thessalonica, Mitilini, Rhodes, Chania and Patra with concrete regions of responsibility and in their work contribute the rest Port Police Authorities in each region.

For the air sector JRCC is supported by Radar of Air force and Civil Aviation. JRCC in its region of responsibility provides services in all the vessels, ships, individuals or aircrafts that are in distress independent of their flag. Also it is interested for each incident in any point on the world, when vessel in distress under Hellenic flag or owned by Hellenic ship owners, or work on it Hellenic seamen, collaborating with the responsible Centre of SAR region.

Further the above, JRCC is dealing for the rescue of any means, independent flag and nationality of seaman or passengers, in any part of the world it is, if JRCC is the first recipient of signal of distress, until the competent for the region centre undertakes the management of incident.

The concretization of planning for SAR is enforced by the Port Police Authorities, which are directed and coordinated by the JRCC. The operational control of SAR means that are disposal for SAR is enforced by the JRCC or the Port Police Authorities. 
The HCG for the implementation of its work and in order to cover its operational needs allocates big number of navigable means. The navigable means that allocate today the HCG are 271 , various types and various operational possibilities, as are analytically reported below:

a. Patrol boat of open sea, type SAAR 4.

b. Patrol boat of open sea, type EUROPATROL.

c. Patrol boats, type ABEKING.

d. Boats for open sea of multiple usefulness.

e. Boats of pollution fighting (Detergents).

f. Salvage vessels. Type: ARUN-HALMATIC.

h. Coastal fast patrol boats. Types LCS 53', LCS 57', L65' and D45Z.

i. Specialized fast patrol boats. Types: MAGNA ONDA- MIL 38-MIL 40 - CB 90 HCG .

j. Prosecution boats (inflatable). Types: TOP GUN MOSTRO, OCEANIC 9000 STEALTH, GIBLI 1025 ([NIREAS]), MOSTRO-DROMOR-AVON-APATSI (etc).

\section{k. Prosecution boats (GRP). Types: D26Z-D27Z-SUPER ONDA-ONDA - JET SKI (etc).}

The air means that can be used by JRCC for SAR operations are mainly disposed by the Air force. Also in the disposal of JRCC are the helicopters type Super Puma and air means that HCG use for surveillance of coasts. Also, exist six helicopters type Dolphin. To the above must be included also a big number from HCG land means that assist and contribute in SAR operations, when this is required.

In order to be achieved most effective providing of SAR services in air and maritime accidents, in 1982 started the operation of an international satellite system called COSPAS- SARSAT (Note 44) which provides direct information and precise coordinates in order to assist the SAR as soon as possible, because it is given the possibility of notification of the precise position of the vessel or aircraft being in distress. Hellas participates in the above program and has installed Hellenic land satellite station (LUT/MCC) from 2008.

\section{Management and Information Systems of Vessels Trafficking}

\subsection{LRIT (long range identification and tracking of ships)}

The concretization of system of Recognition and Localization of Boats of Long Distance constitutes an important system in the guarantee of human life in the sea.

On 1-1-2008 entered into force the modifications of chapter V of SOLAS Convention, which were adopted by the Decision MSC 202 (81) /19.5.2006 of IMO. With these modifications was added a new Regulation 19-1 under the name" Long Range Identification and Tracking of Ships".

With this Regulation are determined requirements of supply of passenger vessels, cargo vessels up to 300 gross tonnage (gt) as also to the mobile units of offshore drillings with system of recognition and localization of ships of long distance (Long Range Identification and Tracking).

The supply is direct for vessels that will be manufactured afterwards of $31^{\text {st }}$ of December 2008. For vessels that were manufactured before $31^{\text {st }}$ of December 2008 the supply has been realized by the first inspection of radio installation afterwards of $31^{\text {st }}$ December 2008 depending the regions in which they are activated.

Systems LRIT that will be installed in vessels under Hellenic flag should be approved its type and also to fill the technical and functional requirements of Decision MSC 210 (81) of IMO (Note 45).

The LRIT information (map 2 about here) that emits the vessels via the equipment that they allocate includes:

- The identity of the vessel.

- The position of the vessel and

- the date and the hour of the stain

According to a decision of the EU Council, it functions under the responsibility of EMSA a European Data Center, for the reception of information from the vessels which bring the flag of EU M-S as well as the management of these information.

The Hellenic Coast Guard provides in the above centre, list of Hellenic vessels which are obligated to carry LRIT system. 


\subsection{Vessel Traffic Service-VTS}

In 1997 the Committee of Naval Safety (MSC -Maritime Safety Committee) of IMO, adopted new models for the Services of VTS (Vessel Traffic Services), which are included in chapter 5 of the International Convention SOLAS (Note 46). Afterwards, IMO and the IALA (International Association of Lighthouses Authorities) published constitution for the concretization, operation and education of personnel of systems VTS (Note 47). Also, the European Union published the Directive 2002/59/EP for the establishment of Community System of follow-up vessels trafficking (Note 48). The directive aims in the creation of Community system of follow-up of vessels trafficking and information, in order to be strengthened the safety and the effectiveness of marine trafficking, to be improved the correspondence of authorities in incidents, accidents, or dangerous incidents in the sea, inter alia with SAR operations (relative is the article 17 of the Directive), and also to be facilitated the prevention and the detection of pollution by vessels.

More specifically with the aforementioned directive were given - provided directions, in order the coastal member States to be in position to exchange the information that collect in the frame of missions of follow-up of marine trafficking in their regions of competence. The Community system of exchange of shipping information "SafeSeaNet", which has been developed by the Committee in agreement with the member States, includes side network of exchange of data as also standardization of main available information for the vessels and their cargo (warnings and submission of reports). It thus provides the possibility to be located in the source and to be announced in each authority precise and actualized information with regard to the vessels which are in the European waters, the movements and their dangerous or pollutant charges, as well as with regard to marine incidents.

\subsection{Vessel Traffic Management and Information System (VTMIS) (Note 49)}

VTMIS is the National Central System that receives information from local VTS centers, processes them centrally and also distributes them accordingly. VTMIS center has a key role and constitutes precious tool for analysis of trafficking data and for strategic planning. At the same time it constitutes the main interlocutor with other peer centers that are developed in the countries of EU, or with the national centers of receiving /sending information.

The central system of VTMIS is based in the Hellenic Coast Guard and is connected with centers of VTS (function in Piraeus, Patras, Corfu, Antirrio, Igoumenitsa, Rafina and Lavrion) (table 3 about here). Each centre of VTS processes all the elements of vessels trafficking in its responsibility region which are collected by the local stations of sensors.

\subsection{EUROSUR (European Border Surveillance System) (Note 50)}

Finally is making an effort of growing European System of Monitoring of Borders, which in its complete growth will contribute in the acquisition of more complete picture in the sea borders and at extension in the improvement of interventions effectiveness. Its growth in the southern and Eastern region of EU is expected to constitute a road map (pilot) for the rest regions of EU.

This system aims:

a. - in the reduction of the number of illegal immigrants who are entering in the EU without be located,

b. - in the reduction of high percentage of deaths of illegal immigrants, with the rescue of more human lives in the sea.

As it is known a big number of illegal immigrants travel under particularly awkward conditions and they undertake enormous personal dangers in their effort to enter illegally in the EU hidden in vehicles, in commercial ships, etc.

The practice which is followed to travel in vessels without absolutely keeping any requirement for safety voyage has led to the increase of number of deaths of illegal immigrants to Atlantic Ocean, between Africa and Canarias Islands as also in Mediterranean Sea.

The mentioned system aims between the other in the localization in time mainly of small ships, a fact that will allow the wider conduct of SAR operations and consequently the rescue of more human lives in the sea, and c. - in the aid of internal safety of EU as total, contributing in the prevention of cross-border crime.

\section{Attitude of Turkey - Contestations, Aspirations, Views}

As have been mentioned before in the delimitations of Athinai - Istanbul FIRs, Turkey had agreed and in particular with its acceptance for a long time had contributed in their consolidation. Concretely with the 
decisions of ICAO Council on 23-6-1952 and on 15-5-1958 were delimited apart from FIRs Athinai and Istanbul and the regions of SAR responsibility with way that their limits to coincide absolutely with the limits of corresponding FIRs regions (Note 51).

However from 1974 till today started to be observed by Turkey a factual contestation of limits of Athens FIR, with mass infringements of Turkish aircrafts and violations of national air space (Note 52) disputing totally the status quo in the Aegean Sea. This practice consists in flights of air forces aircraft without warning and deposit of flight drawing, the keeping of ICAO rules, or the application for entry authorization in the Hellenic air space. It is pointed out that Turkey disputes the territorial interval air space between 6 and $10 \mathrm{~nm}$ from 1974 (Note 53). In the total contestation are included also the competences of Hellas for providing SAR services for vessels and aircrafts (Note 54).

The first contestation of Hellenic FIR was realized in July 1974, with the publication of NOTAMs which declared sections of Eastern Aegean into Hellenic FIR AS dangerous regions alleged by Turkey the security of its coasts. Afterwards of Hellenic protests they recalled. Following by the NOTAM 714 that was published on 6 August 1974 constitutes the more explicit event of reviser policies of Turkey.

With this particular NOTAM, Turkey sought extension of its jurisdiction space inside the FIR of Athens, creating a new limit line with new points of report (maps 4 and 5 about here). Concretely it was notified that each aircraft that entry easterly of this line should report to the FIR Istanbul and also should submit drawings to the competent Authority (Air Traffic Control Center). The Turkish policy from then until today remains immutable (Note 55).

Turkey has from 1989 (Note 56) unilaterally adopted as region of SAR responsibility "being in danger aircrafts and marine means" and with law from 12/2001 (Note 57) roughly the half Aegean with also Hellenic regions with Hellenic islands (table 6 about here) (Note 58).

With the above legislation Turkey determined as responsibility of providing SAR service the half roughly space of Aegean, the occupied Cyprus and a section of Nicosia FIR.

Concretely with the aforementioned Regulation are clarified the activities of SAR responsibilities of Turkish authorities and are delimited their competences for providing SAR services in being in distress "aircrafts and marine means" in the land, air, the surface of sea or under, inside the Turkish air space, the land borders, the internal and territorial waters and the "surfaces of open seas or under them".

With the Turkish regulation are disputed of course and factually the Hellenic competences and the Hellenic jurisdiction on SAR issues in the Aegean Sea and inside the Athens FIR, as delimit two areas inside the FIR Athens, one Hellenic and one Turkish. In the Turkish area are included Hellenic national air space and international air space under Hellenic jurisdiction.

From the regulations of Chicago Convention and specifically from Annex 12 reveal clearly that the competence and the responsibility for providing SAR services in being in distress aircrafts inside a FIR region concern actions and in air and in the marine space with the subscription of vessels and aircrafts under the management of one Co-ordination Center. The Turkish regulation determines in article 6 that the "responsibility of SAR that is recognized according to the rules of ICAO in the air space which is over of the open seas does not cover the actions of SAR in the sea", disputing straightly the competences of Hellenic Authorities as in the same regulation in article 9 is determined that "the services of SAR that are offered for the marine and aircraft means which are in distress into the Turkish air space, in internal and territorial waters and in the open seas according to article 6".

In the article 6 also of Turkish regulation is determined that "the regions out of Turkish territorial sea where will be offered SAR services will be determined with agreements that will become with the related States".

The last formulation of provision of article 6 is reported in the point of 2.1.4 of Annex of the Convention 1979, which however is reported exclusively in processes of SAR services for maritime accidents, as revealed clearly from the content of provisions of Hamburg Convention.

More specifically regarding SAR (Note 59), Turkey deliberately does not make discrimination between processes of rescue of vessels and aircrafts in order to lead Hellas to proceed in delimitation based on agreement, a zone for SAR in the Aegean, inside Athens FIR that will cover actions of SAR for being in distress vessels but also for being in distress aircrafts while as already has been analyzed exist already delimited under Hellenic jurisdiction based on ICAO procedures. 
The delimitation unilateral that is attempted by Turkey is arbitrary and it is contrary to the international law since according to the Hamburg Convention the delimitation of areas of SAR responsibility should become with bilateral agreements (Note 60). The agreements however are supposed to take into consideration the corresponding limits of FIR regions regarding the areas of responsibility for aeronautics rescue. Besides in the point 2.1.7 of Annex of Convention 1979, is determined that the "delimitation of SAR regions is not related and will not be offended the delimitation of any border between the States". In the meaning of borders it should be considered that are included also the delimitations based on the periodical agreements of ICAO and areas of responsibility for aeronautics SAR.

On 7-4-1989, ICAO confirmed that the regions of responsibility of Hellas and Turkey with regard to the aeronautics SAR remain immutable, as these have been determined and agreed in the frame of organization. Also, the modification of Annex 12 of ICAO for SAR maintains the principle of determination of regions responsibility with periodical agreements, something that confirms the Hellenic competence for SAR in all the Athens FIR.

It is important to mention here that IMO had asked from Hellas and Turkey to agree for their limits of responsibility, but it has not been rendered possible because Turkey as has already reported claims as region of jurisdiction all the Eastern Aegean.

From 1996 Turkey does not accept and does not approve in ICAO level, Hellas to develop rescue means in the Hellenic islands of Eastern Aegean invoking that there are demilitarized. With this way it is presented as alone capable to enforce the competence of SAR in Eastern Aegean based that it is the only one that have rescue means (Note 61).

It is pointed out that the final text of modification of Annex 12 of ICAO regulation on SAR which was placed in force on 11/2004, aims at the harmonization of aircrafts and maritime SAR operations and at the organization after collaboration of neighboring States, common regions of SAR operations in order to be reduced the cost of operations.

In the above mentioned Annex, is determined that the limits of SAR Regions are determined with process proportional with the one that is forecasted for the determination of limits of FIRs Regions. The limits of regions responsibility of every State for SAR services of being in distress aircrafts in section of international air space, as well as above the open sea, are determined with periodical Agreements that are approved by the ICAO Council. These limits are determined in a way that they coincide with the corresponding limits of FIRs Regions (Annex 12, Chapter 2, Constitution 2.2.1.1).

Up to November 2004 the determination of SAR regions limits became based on the borders of States. However with the modification of the Annex, this regulation has been suppressed and forecasted that "the determination of SAR regions is determined based on the technical and operational possibilities of states". It is obvious that this forecast helps Turkey, which specifically in the region of Eastern Aegean allocates means with high technical and operational possibilities overwhelming continuous efforts for improvement of its operational possibilities. These regulations will create probably new data regarding the limits of SARs between Hellas and Turkey (Note $62)$.

Impression causes the change of Hellas attitude, which consent on that. According my opinion the policy that Hellas followed in that particular case was misplaced as the continued revisory policy of Turkey surly will exploit this new development.

Turkey declared as it is forecasted in the article 38 of Chicago Convention and the Decision of ICAO issued on $21^{\text {st }}$ November 1950, that it has no objection for deletion of term "borders" and replacement with the term "technical and operational possibilities". Besides with the technical and operational infrastructures that creates in the region it is likely to be encouraged their options.

The approach of Turkey for SAR items in the Aegean Sea is reflected in the Annual Reports of Activities that are published in the web page of Turkish Coast Guard Command (TCGC-Sahil Guvenlik Komutanligi) (Note 63) as well as in the statements of Turkish General Staff of Armed Forces and Turkish Administration of Naval Forces for the SAR exercises that are taken place in the Aegean Sea.

Concretely SAR regions are included based on the mentioned before reports (map 6 about here). It deserves to be mentioned that in the page 23 of the Annual Report of Activities on 2006 it is quoted that [Hellas and the "Greek-Cypriot Administration of Southern Cyprus", specifically in the direction of decisions that were received by the European Union, using resources of European Union accelerated the programs that concern in the control 
of marine circulation in Aegean and in Eastern Mediterranean. Taken into consideration the philosophy, that the region that we cannot check is not ours, we should immediately acquire systems of our seas control].

In the page 38 of the same report it is quoted also that: "The TCGC (Sahil Guvenlik Komutanligi) gives big importance in Aegean and in Eastern Mediterranean, specifically in SAR activities, which constitute the most important mission because the human dimension. In that frame started an henceforth actively the operation of SAR system which is supported by the satellites under the name COSPAS - SARSAT. The acquisition of this possibility has big importance, in combination with the ratification in international level the regions of SAR that we have announced in Aegean and Eastern Mediterranean".

Regarding the statements and the scripts of Turkish intersectorial SAR exercises in the Aegean sea under the names Deniz Aslani Anadolu Yildizi are pointed out the following based on information posted at the websites of the aforementioned institutions (Note 64).

The specific exercises are drawn by the Turkish General Staff of Armed Forces and participate military and political institutions that are involved in SAR. The exercises are shown by representatives of press and foreigner observers.

Aim of the exercises is to be presented the capabilities of Turkey on operations issues of direct help and collaboration, with the co-ordination of all institutions that are dealing with SAR. In the exercises participate various types of vessels, aircrafts and helicopters and means of ministries of Health and Transports, SAR Centre of ministry of Shipping, naval forces, air forces and the TCGC.

Script concisely regarding SAR, forecasts the emission of signal of distress from commercial vessel that sails in the international territorial sea between the Hellenic islands Lesvos and Chios. The main Centre of SAR Co-ordination of the ministry of Shipping informs the SAR Co-ordination Centre of TCGC, while at the same time is requested the subscription of corresponding centre of Armed Forces. Following is disposed by the Administration of Land Forces helicopter for SAR, the Administration of Naval Forces allocates frigate, two corvettes, and team of frogmen with boats, the Administration of Air Forces allocates an aircraft and a helicopter for SAR, the TCGC allocates a vessel and a helicopter for SAR and the Administration of Special Forces allocates a helicopter and a team for SAR of natural destructions.

\subsection{Armament programs (TCGC - Sahil Guvenlik Komutanligi)}

The executive Committee of Defensive Industry has decided the concretization of the following armament programs that concerns in the construction from Turkish companies vessels of various types. The mainer programs concern:

Four vessels boats of search and rescue of open sea, 1700 tons, with possibility of helicopter transport. Already have been selected the constructive companies and has started the shipbuilding of vessels, which will have length of 88,6 meters and width of 12,2 meters. These vessels will have the possibility of attempting with unfavorable meteorological, they will execute SAR missions, patrol, dissuasion of smuggling, illegal immigration, control, monitoring, dissuasion of marine pollution and extinguishment of fires. The first vessel under the name Dost has already launched at the end of 2011. The rest of three vessels with names Guven, Umut and Yasam will be delivered in 2012 (Note 65).

Seventeen vessels of 25 tons and twenty two vessels of 90 tons. The final receipt of seventeen vessels of 90 tons have already taken place and is expected the receipt of the rests. The vessels will be used for the direct intervention and dissuasion of illegal activities, as well as for the implementation of SAR operations (Note 66).

In the frame of rearrangement that is taken place now, the Turkish Coast Guard Command in 2014 will allocate 7.000 executives, with perspective this number to be increased at 10.000 executives.

Also allocates 65 bases/ports/positions where stationed helicopters [AB]- 412, aircrafts type CN-235 for monitoring, mobile radars, which supplement the list of 160 marine means.

From the above revealed that the Turkish Coast Guard Command with the increase of its personnel but also with its qualitative and numerical modernization in maritime and aircrafts from 2011 and afterwards, will have very important possibilities for conducting SAR operations in the space of Aegean Sea but also in Eastern Mediterranean. It should be marked that in a potential clash the above forces will constitute a powerful arm of Turkish armed forces, since the activity of Turkish Coast Guard Command is focused in two sectors that are related with the Hellenic-Turkish relations and recommend points of friction: the illegal immigration and the sector of SAR. 


\section{Conclusions}

Turkey in a legal level but also factually, disputes the international legal framework of Aegean Sea as it has been shaped via the international legislation and in consequence disputes the recognized and guaranteed jurisdictions of Hellas. The intensity that is being created in the Aegean sea from the policy enforced by Turkey is also transported to the international organizations, with a view to be created erroneous impressions that exists insecurity in Aegean and as consequence must change the delimitations and the jurisdictions in the FIR Athens in favor of Turkey.

The effort of Turkey is continuous in order to present Aegean as a marine and air space of special conditions, which its legal regime should be regulated not on based of maritime law, the law of airspace and the regulations of ICAO but in the base of bilateral agreements between Hellas and Turkey so that will exist new delimitations of marine and air areas in Aegean, FIR regions, areas of SAR responsibility. In any case Turkey aims with its revisory policy and with the practices that enforce in the Aegean Sea to create new data in its favor. For the satisfaction of its demands Turkey has shaped the theory of "vital space" and according to their arguments the differences between Turkey and Hellas should be solved in the base of principles of "lenience of" "reciprocity" and "fairness" and not on the base of the international law, which Turkey disputes.

The revisory policy that follows Turkey in Aegean Sea is intensely likely to lead to crisis or to a "hot" episode. The violations and infringements of Athens FIR are intense and almost in daily base. In frequent base are created intensities from maritime accidents that are taken place in the space of Aegean Sea, as Turkey attempts to offer SAR services, in regions in which institutional does not have competence but also without for this to inform the responsible competent Hellenic authorities.

It must be noted that until 1974 Turkey had accepted the status quo in the Aegean Sea, participating in all international processes in order to delimit - regarding the present study - the regions of SAR. The revisory policy that follows reveals as result also from the equipment which realizes the Turkish Coast Guard Command in escalated competitive relations. More specifically the supply of vessels for open sea obviously has been drawn with a view to exist for longer duration in the presence of Turkish vessels in the international sea of Aegean sea, in order when a maritime incident is happening the Turkish authorities to deal with passing the responsible Hellenic authorities. With this way, in incidents that are taken place are creating fait accomplices because when the Hellenic authorities are sending means the Turkish means do not leave and there is no chance to leave because SAR are peaceful operations and not war or other similar operation.

Besides the character of SAR operations, is used by Turkey as vehicle for the creation of accomplished situation in the Aegean sea. Through SAR are disputed the FIR Athens and the competences of Hellenic authorities, the national air space etc. Hellas until now provides excellent services in the particular sector with the creation of JRCC and the collaboration of all institutions for the protection of human life in the sea. Simultaneously with the supply of four vessels for Open Sea - (PATH), strengthen its operational possibilities for providing protection in the human life in the sea. In above must be added the helicopters type SUPER PUMA, the special SAR vessels that allocates the HCG which are disposal to the Port Police Authorities of Aegean Sea in order tobe covered operationally all the space of Aegean. It also must be examined the permanent stationed of HCG helicopters at the islands of Aegean, for instance Skyros and Thira which allocate relative infrastructures, so that will be improved more the time of correspondence in SAR incidents.

Consecutively it must be taken under consideration that Hellas allocates one of the largest and more powerful fleets in the world. This practically means that in the space of Aegean dominates the Hellenic flag and in consequence the direct providing of help from Hellenic vessels (without be overlooked the obligations of other vessels as are determined by the current legislation).

At the same time the installation of systems of management and information of vessels trafficking which have been developed also help in providing SAR services. Hellas also participates in COSPAS - SARSAT system from 2008, strengthening still more its technical possibilities for direct correspondence in SAR incidents.

Regarding the jurisdictional procedures of resolution of solving appeared differences as contestations of delimitations of areas of competences as FIR, or the area of responsibility of SAR services the procedural possibilities are forecasted in the articles 54,84 and 88 of Chicago Convention.

\section{References}

Athanasiou, A. (2010). Danger of National amputation. Epikaira, 54, 78-79.

Andreou, A. (2009). Code behavior ask Ankara for Den Haag. Ta Nea, 10. 
Cansu, C. (2009). Taking the fight out of dogfights. Hurriyet Daily. [Online] Available: http://www.hurriyet.co m.tr/english/domestic/10912002_p.asp

Daousis, E. (2010). The Turkish contestations in Aegean, legal and political aspects. IAA (Defense Analysis Institute), 12, 23-26.

EPIKAIRA. (2010). Imperative the need of briefing of Parliament and population, View, 54, 80-81.

Irakleidis, A. (2007). Implacable neighbors Hellas - Turkey the conflict of Aegean (p. 74). Sideris, Athens.

Kouloumpis, T., \& Yfantis, K. (2003). Altering the dilemma of Security in the Aegean (Volume B, pp. 99-159). Modern Hellenic Foreign Policy, a total approach, Sideris, Athens.

Giokaris, A. (1990a). The Hellenic - Turkish differences dangers and possibilities (pp. 31-39). Studies of Marx Centre of Researches, Line II, Modern Season, Athens.

Giokaris A. (1991b). The jurisdictions of coastal state in the air space, national and international (pp. 151-152). Sakkoulas, Athens - Komotini.

Giokaris, A. (1994c). The international legal regime of Athinai FIR, in points of friction in the Hellenic-Turkish relations (pp. 5-8). ELIAMEP (EAIAMEП), Sideris, Athens.

Giokaris, A. (1996d). In Perrakis St., Sakkoulas, Athens - Komotini, The Hellenic air space and the FIR Athens. The repercussions from the new Convention of UN for law in the sea (1982) (p. 65). Aegean Sea and the New Law at Sea.

Giokaris, A. (2002e). In Perrakis St., Sakkoulas, Athens - Komotini, Contestation from Turkey of delimitations and meters of management with defensive orientation, in Aegean, Developments and prospects of resolution of Hellenic -Turkish conflicts, 73.

Iliadi, I. (2009). The next crisis will concern SAR. Ethnos tis Kyriakis, 14.

Karbounopoulos, P. (2009). Exercise - challenge of Turks in Aegean. SFINA, 12.

Kladi - Eystathopoulou, M. (2007). Subjects of Air Space Law. Sideris, Athens.

Lazos E. (2002). Helicopters of Special Missions. The special dimension of Army Aviation. Defense and Diplomacy, 139, 80-87.

Lampropoulos, A., \& Tsakiri, G. (2009). With recipe of Imia. Eleutherotypia, 12.

Lygeros, S. (2009). Dangerous crescendo of expansionism. O Kosmos tou Ependyti, 6-7.

Meletis, N. (2009a). With the look in the elections lose "battles" in Aegean. Ethnos tis Kyriakis (p. 18).

Meletis, N. (2009b). Hegemonic rehearsal of Ankara in Aegean. Ethnos tis Kyriakis, 12.

Meletis, N. (2010a). Appointment for afterwards the elections gives the foreign policy. Ethnos tis Kyriakis, 20.

Meletis, N. (2010b). Hellenic-Turkish and Cypriot tally in the agenda of Erntogan. EPIKAIRA, 54, 76-77.

Minagias, C. (2010). The geopolitical strategic and military force of Turkey. Tourikis, Athens, 222.

Memorandum of National Subjects. (2006). General Staff of National Defense, Division of Defensive Policy, Athens.

Mpatrakoulis, T. (2010). Oil of Kastelorizo and the deficit strategic. Ethnos tis Kyriakis, 55.

Perrakis, S. (1996). Questions of application of international law in the Aegean. Political dimensions, (pp. 363370). Athens - Komotini, Sakkoulas.

Rozakis, C. (1988a). The international legal regime of Aegean and the Hellenic-Turkish Crisis, in the Hellenic -Turkish Relations, 1923-1987, ELIAMEP (E $I$ IAMEП) (p. 469), Knowledge, Athens.

Rozakis, C. (1989b). In Konstas, D. \& Tsardanidis ,C. S., The Hellenic - Turkish relations: The legal dimension (Vol. B, p. 45). Modern Greek Foreign Policy.

Sazanidis, C. (1988). The Hellenic -Turkish relations in five-year period 1973-78 (p. 27). Thessaloniki.

Spanos, N. (1997). SAR in the sea. J and J Hellas, Piraeus.

Spanou, A. (2010). In the "ice" the national. Free Sunday, 13.

Tsakonas, P. (2003). Socializing the opponent. The Hellenic Strategy of Balance of Turkey and the Hellenic -Turkish Relations (Volume B, pp. 79-87). Modern Hellenic Foreign Policy, a total approach, Sideris, Athens. 


\section{Notes}

Note 1. The first SAR operations were realized during the Second World War and more specifically during the Battle of England. They included hydroplanes which under the escort of fighting aircrafts undertook the rescue of crews in the sea. Following Germans in SAR operations used also helicopters. The Americans in the war of Korea established Service of Rescue under the title (Air Rescue Service) the contribution of which led to the salvation of thousands of soldiers, while SAR services were also carried out in the war of Vietnam which also led to the salvation of thousands of soldiers. Lazos E (2002). "Helicopters of Special Missions. The special dimension of Army Aviation. Defense and Diplomacy, 139, p.p. 80-87.

Note 2. Terms and definitions are according to Chapter 1, of Annex of B' Part of PD 201/2000 (A' 181). The same terms and definitions are similar and in Chapter V: Safety of navigation in Regulations 2 and 7 of Law $1045 / 1980\left(\mathrm{~A}^{\prime} 95\right)$ as it was modified and is in effect.

Note 3. See article 2 of Law 1844/1989 (A'100) in which is determined that "the region of SAR that is reported in paragraphs 2.1.4 and 2.1.5 of the Annex of this Convention is the region inside which Hellas has already undertaken the responsibility for SAR aims which has been determined according to the relative Convention of Chicago and the periodicals Drawings of ICAO as well as the Regulation of 15 Chapter V of SOLAS 1960. This region that constitutes the most suitable regulation according to the meaning of paragraph 2.1.5 o the Annex of this Convention, was announced to IMO with the document No. the 44/7-1-1975 issued by the Ministry of Mercantile Marine and in this region Hellas continuously for a long time realized SAR operations".

Note 4. Spanos N.. SAR in the sea. J and J Hellas, Piraeus, 1997.

Note 5. See document with No. 3221.03/03/10 issued on 23-02-2010 by the Ministry of Citizen Protection/HCG Headquarters/Search and Rescue Division/ Department B, titled "Memorandum of Actions of HCG for a vessel in a awkward place inside region of responsibility of Hellas SAR".

Note 6. See "Ethnos tis Kyriakis", on 15-03-2009, p. 14, article of Iliadi I., titled "the next crisis will concern SAR". Concretely it is quoted that [..... "The next Hellenic-Turkish crisis will concern SAR subjects", insist a lot of valid analysts in the Hellenic -Turkish subjects and point out that our country delays characteristically in these subjects. It is characteristic that when enter in Aegean big shaping's of Turkish aircrafts are always accompanied by helicopter, in order if happens an accident to be the first that will hurry for SAR in the place of accident....']

Note 7. Afterwards the conflict of two aircrafts the Turkish pilot was ejected and fell in the sea with parachute (inside the FIR Athens in international waters southerly of the Hellenic island Karpathos). Afterwards the mobilization of JRCC in the region hurried maritime and air means of Navy and HCG. The Turkish pilot was collected by a cargo vessel under Panama flag. The Hellenic rescuers who reached in the region with SUPER PUMA as well as floating patrol boat of HCG, offered to provide help to the Turkish pilot which denied invoking his even physics situation. After demand of Turkish side was allowed his receipt by Turkish helicopter.

Note 8. On 25 December 1995 (night hours) the Turkish vessel under the name "Figken Akat" ground in the rocky islands of Ymia of Dodekanisa prefecture. The skipper of the vessel denied the intervention of Kalymnos Port Police Authority in order that the vessel to be detached from Hellenic towboat, supporting that the vessel ground in Turkish region and the competence of towage belong in Turkish authorities. Finally after consultations two Hellenic towboats detached the vessel and accompanied it until to the Kioyloyk port in Turkey. Coincidentally the same day Turkish fighting plane completely equipped fell in the marine region of Lesvos after fighting in the air. The Turkish pilot was rescued with Hellenic help.

Note 9. See "TA NEA" on 04-02-2009, p. 10, article of Andreou A., titled "Code....behavior" ask Ankara for The Hague" and article of Cansu Camlibel in the English publication of Hurriyet Daily News titled "Taking the fight out of dogfights".

Note 10. For the Hellenic-Turkish differences and the Hellenic views exist large bibliography. Indicatively see analytically "Memorandum of National Subjects", General Staff of National Defense, Division of Defensive Policy, Athens, June 2006. More specifically for SAR p.p. 16-17. Also see Irakleidis A., Implacable neighbors Hellas - Turkey the conflict of Aegean, Sideri, Athens, 2007, p. 74, Kouloumpis Th., Yfantis K., Altering the dilemma of Security in the Aegean, p.p. 99-159, in the Modern Hellenic Foreign Policy, a total approach, Volume B', Sideris, Athens, 2003, Tsakonas P.,"Socializing the opponent The Hellenic Strategy of Balance of Turkey and the Hellenic -Turkish Relations", in the Modern Hellenic Foreign Policy, a total approach, Volume B', Sideris, Athens, 2003, p.p. 79-87, Perrakis St., Questions of application of international law in the Aegean. Political Dimensions, p.p. 363- 370 in Aegean Sea and the new law of sea, Athens - Komotini, Sakkoylas. 
Note 11. See "Free Sunday", on 07-11-2010, p. 13, article of Spanou A., titled [In the "ice" the national], in text of which are reported the following: [".......... In the last meeting of Turkish ministerial council and in the frame of briefing on the recent meeting Papandreou - Erntogan in Athens was discussed, based on information in the Turkish Press, the possibility of escalated extension of territorial sea. Besides the Turkish minister of Territory Mpagis E., declared with meaning that has been achieved important progress in the dialogue, that will be announced "when comes the hour"]. Also see Meleti N., EPIKAIRA, copy 54, "Hellenic-Turkish and Cypriot tally in the agenda of Erntogan", p.p. 76-77, in the same Athanasiou A., "Danger of National amputation", p.p. 78-79, and in the same "VIEW, Imperative the need of briefing of Parliament and population", p.p. 80-81.

Note 12. Besides this law Hellas has proceeded in the ratification of Law 210/1947 (A' 34) and the Law 212/1947 (A'36).

Note 13. IMO convened international conference in Hamburg from 09 until 27 April 1979 in order to ensure that all the coastal states will undertake in their space the responsibility to organize Services for the protection of human life in the sea. Result of Conference is the particular Convention.

Note 14. The legislation from 09 till 12 has been developed in the past few years in the EU, aiming at the protection of human life in sea.

Note 15. It was determined area of territorial zone of $10 \mathrm{~nm}$ from the coasts for Aviation and policing reasons.

Note 16. It was determined zone of six nm from the coasts.

Note 17. The convention of Chicago today is accompanied by eighteen Annexes that cover problems of transports in air and trafficking. From the day of its ratification until today has been modified seven times and has adhered by 189 states. According to Part II, articles 43 and next of the Convention was established a new organization, the Organization of International Civil Aviation (ICAO) which replaced the International Committee of Aviation (CINA). ICAO has been connected with agreement of connection with UN from 1947 (see more on website www.icao.int).

Note 18. The nine regions are Europe, Middle East, Asia/Pacific, Africa, Latin America and Caribbean, Southern America, Northern Atlantic and North-American Region.

Note 19. Relative for FIR is annex 2 (Rules of Air Trafficking) and 11 (Services of Air Trafficking) of Chicago Convention.

Note 20. The Air navigation Committee is forecasted by the article 56 of Chicago Convention and is constituted by fifteen members who are proposed by the member states and are appointed by the Council. It has advisory character and it is responsible to examine all the subjects that concern the air trafficking as also to propose solutions. Its main work is the drafting of Convention Annexes and the submission of consultations in the Council regarding technical subjects.

Note 21. See Giokaris A., The international legal regime of Athinai FIR, in points of friction in the Hellenic -Turkish relations, ELIAMEP (EАIAMEП), Sideris, Athens, 1994, p.p. 5-8.

Note 22. See Kladi - Eustathopoulou M., Subjects of Air Space Law, Sideris, Athens, 2007, p.p. 132 -133.

Note 23. It was established according to Law 5100/1931 (A'193).

Note 24. It was adopted in 1950 and from that time has been modified eight times (the first publication was realized on the 25-5-1950 and was placed in force on 1-3-1951). The modifications follow the following chronological line: 1952 (2nd), 1956-57 (3rd), 1959,1962,1964,1965 (4th), 1970, 1972 (5th), 1974, 1975,1980,1990,1993 (6th), 2001, 2004 (7th) and 07/2004 (8th). The last modification aimed at the harmonization of air and marine SAR operations and at the organization after collaboration with neighboring states, common regions of rescue operations in order to be reduced the cost of operations.

Note 25.With the revision of Convention for maritime SAR on 1979 from the international organizations IMO and ICAO were adopted the International Handbook of Aeronautics and Marine SAR (IAMSAR Manual) that aims at the harmonization of rules with regard to the providing of SAR services at cases of aircrafts and maritime accidents. The handbook in question replaced the two handbooks of IMO (MERSAR Manual 1971) and (IMOSAR Manual 1978).

Note 26. It is noted that preparatory work had been realized in Second Periodical Air navigation Conference of Middle East held in Istamboul in 1950. In this conference with the attendance of Hellas and Turkey was decided the distribution of European air space according to the Decisions of ICAO. 
Note 27. See "Air navigation Map of Hellas", ICAO, (1: 500.000), Ministry of Transport, Service of Civil Aviation, Division of Air Trafficking, department of Aeronautical Information and Maps, 1981.

Note 28. For the limits of the Hellenic national air space has been developed argumentation that it is not consistent the existing of different length in the air space from the length of territorial sea. Irakleidis A., op.cit. p.p. $317-336$.

Note 29. See Giokaris A., The jurisdictions of coastal state in the air space, national and international, Sakkoula, Athens - Komotini, 1991, p.p 151-152.

Note 30. See PD 396/1984 (A' 139). According to Annex 15, the Services of Aeronautical Information of States have the responsibility of collection, distribution and disposal of aeronautical information to the all interested parts for use from all categories of air activities for the smooth distribution of air trafficking in their national air space and in the regions except national air space in which has been assigned to them the control of air trafficking (FIRs).

Note 31. See Rozakis Ch., The Hellenic - Turkish relations: The legal dimension, in the collective volume Modern Hellenic Foreign Policy, editors Konstas D., and Tsardanidis Ch., Sakkoula,Vol. B, p. 45 and next.

Note 32. See Giokaris A., op.cit. note 29, p.p. 23-25. Also Giokaris A., The Hellenic air space and the FIR Athens. The repercussions from the new Convention of UN for law in the sea (1982, in the collective volume, Aegean Sea and the New Law at Sea, editor Perrakis St., Sakkoula, Athens - Komotini, 1996, p. 65 and next.

Note 33. See Kladi - Eystathopoulou M.,op.cit., p.p. 156-157 and footnotes 480-491.

Note 34. See Sazanidis Ch., The Hellenic -Turkish relations in five-year period 1973-78, Thessalonici, 1979, p. 27, Rozakis Ch., The international legal regime of Aegean and the Hellenic -Turkish Crisis, in the Hellenic -Turkish Relations, 1923-1987, ELIAMEP (EAIAMEП), Knowledge, Athens 1988, p. 469, Kladi Eustathopoulou M., op.cit., p.p. 156-161.

Note 35. See Kladi - Eustathopoulou M., op.cit., p. 158, footnote 496.

Note 36. See Kladi - Eustathopoulou M.,op.cit., p. 159-160, footnotes 497, 498.

Note 37. See Giokaris A., Contestation from Turkey of delimitations and meters of management with defensive orientation, in Aegean, Developments and prospects of resolution of Hellenic -Turkish conflicts, editor Perrakis St., Sakkoula, Athens - Komotini, p. 73 and next.

Note 38. See notes 2, 3 and 13.

Note 39. The rescue of surviving individuals from maritime accidents is forecasted clearly in paragraph. 3.1.2 of Hamburg Convention.

Note 40. See Kladi -Eustathopoulou M.,,op.cit, p. 175.

Note 41. It must be noted that the discussions on Hamburg Convention were realized in 1979, five years afterwards the invasion of Turkey in Cyprus and five years afterwards the appearance of its revisory aspirations in the space of Aegean Sea. It should according to my personal option during the duration of consultations on the drafting of the Convention to have been avoided formulation of sections as 2.1.4,because based on that, Turkey provides the possibility with erroneous legal interpretations invoking the international law seeking revision inversion of existing legal arrangement to its profit and not only on SAR issues. Besides it should have evaluated the experience from the drafting of Conventions, Regulations and Annexes that concerned and concern the air SAR, with the import of resembling provisions in the drafting International Convention something which was not realized.

Note 42. Law 3922/2011 (A'35) and PD 67/2011 (A 149).

Note 43. In JRCC according to Chapter 6, article 5, paragraph 2 of Law 1844/1989 (A' 100), as supervisor is determined a senior officer of HCG. The officer according to paragraph 2 article 1 , unit $\mathrm{B}$, of the MD 1141.1/04/14-07-2011 (B' 1611) is choiced by the Head of HCG.

Note 44. Acronym of the Russian words «Cosmicheskaya Sistyema Poiska Avariynich Sudow» which means Space System for the Search of Vessels in Distress, while SARSAT means Search and Rescue Satellite - Aided Tracking.

Note 45. See analytically LRIT documents issued by the ex Ministry of Mercantile Marine from 1 until 6, with subject "Application of system of recognition and localisation of vessels of long distance (Long Range 
Identification and Tracking of Ships - LRIT) with Nos. 3233.2/50/2008 issued on 05-09-2008, 3233.2/66/2008 issued on 10-12-2008, 3233.2/74/2008 issued on 30-12-2008 and 3233.2/48/2009 issued on 03-07-2009.

Note 46. See the provisions of PD 349/2001 ( $\mathrm{A}^{\prime}$ 235). More specifically in the provisions of this PD and in Regulation 8-2, paragraph 1 is determined that "the Services of VTS contribute in the safety of human life in the sea, in the safety of navigation and in the protection of marine environment, in abutting regions of land in worksites and installations that are established far from coasts from likely unfavorable repercussions of shipping movement". Consecutively in paragraph 3 the same Regulation is determined that the use of this systems is obligatory only in marine regions inside territorial waters of coastal State"

Note 47. See indicatively IMO Resolution A.857(20) - Guidelines for VTS services VTS, IMO Resolution MSC/Circ.1065/13-12-2002), IALA Standards for Training and Certification of Vessel Traffic Service (VTS) personnel, IALA V103, V103-1, V103-2, V103-3, V103-4 - IALA training programmes and certifications for the training and the certification of VTS personnel, IALA Guideline No. 1026 On AIS as a VTS Tool, IALA Guideline No. 1018 On Risk Management, IALA Guideline No 1058 On the Use of Simulation as a Tool for Waterway Design and AtoN Plannin, IALA Guideline No. 1056 On The Establishment of VTS Radar Services, IALA Recommendation V-119 on the Implementation of Vessel Traffic Services, IALA Recommendation V-125 On The use and presentation of symbology at a VTS Centre (including AIS), IALA Recommendation V-127 On Operational Procedures for Vessel Traffic Services, IALA Recommendation V-128 On Operational and Technical Performance Requirements for VTS Equipment, IALA Recommendation V-136 On Participation in the World VTS Guide.

Note 48. It was incorporated in the national law with the PD 49/2005 ( $\mathrm{A}^{\prime}$ 66), while is imminent the incorporation in the national law the directive No. 2009/17/EP (European Parliament and the Council issued on 23 April 2009). With the last directive have been modified provisions of directive 2002/59/EP. From the aforementioned PD are referred the following provisions of Directive to VTS: article 8, article 9 (paragraph 2-3), article 16 (paragraph 1, section a, point three and paragraphs $2-3$ ), articles 22 and 23.

Note 49. See MD 3239.10/01/2003 (B' 1900), PD 61/09-03-2001, PD 107/11-04-2002 and MD 1243.4/01/09/22-06-2009.

Note 50. See COMMISSION STAFF WORKING DOCUMENT, Brussels 10/10/2007, SEC (2007) 1278. Also COM (2007) 574 final, COM (2007) 575 final, SEC (2007) 1279, SEC (2007) 1280, SEC (2007) 1283.

Note 51. These limits were impressed in the special aeronautical maps of ICAO of Civil Aviation Service, according to the Annex 15 of Chicago Convention (AIP Hellas, SAR 0-1).

Note 52. Hellas from the decade of 30s, has delimited its territorial sea waters in $6 \mathrm{~nm}(1 \mathrm{~nm}=1852$ meters $)$ with the Law 230/1936 and the air national space in $10 \mathrm{~nm}$ (in 1931 with the PD $6-18 / 09 / 1936$ ).

Note 53. For this particular subject and the Hellenic argumentation see Giokaris A., op.cit., 31, p.p. 69-79. Regarding a different approach for the particular subject op.cit., note 28 .

Note 54. See Lampropoulos At., Tsakiri G., Eleutherotypia, "With recipe of Imia ...." 8-1-2009, p. 12, Lygeros St., O Kosmos toy Ependyti, 10-11/01-09, "Dangerous crescendo of expansionism", p.p. 06-07.

Note 55. See Kladi - Eustathopoulou M., op.cit., p. 163 and next, Giokaris A., op.cit., note 21, p. 25 and next, the Hellenic - Turkish differences dangers and possibilities, Studies of Marx Centre of Researches, Line II, Modern Season, Athens 1990, p.p. 31-39, Daousis Em., The Turkish contestations in Aegean, legal and political aspects, IAA (Defense Analysis Institute), 12, p.p. 23-26.

Note 56. Concretely on 7-1-1989 were published in the Turkish Newspaper of Government the "Regulation of Turkish SAR" with No. 88/13559 which had been approved by the Turkish Ministerial Council on 11-12-1988 with which is delimited as region of responsibility for SAR missions section of Black Sea, half of Aegean Sea and part of Eastern Mediterranean included also the occupied Cyprus.

Note 57. See Law 2441 which was voted by the Turkish Parliament on 12-12-2001 with which Turkey determined half Aegean (25th parallel) as region in which it would have the responsibility of SAR. According to map that was published in the law in question, Turkey considers as region of its national responsibility on SAR issues roughly three of fourth of Aegean sea, a region that is extended by Turkish beach until Skyros, Easterly of Evia and Naxos Hellenic islands.

Note 58. It is marked that with Bulgaria and the Russian Federation Turkey has signed Agreements on collaboration regarding the marine SAR in Black Sea (IMO, SAR.6/Circ.24, 25-4-2005/9-8-2005, Ref: [T]2-[O]SS/2.6 and IMO, SAR.6/Circ.25, 25-4-2005/12-8-2005, Ref.T2-OSS/2.6). 
Note 59. In the frame of the Summer Conference of NATO in Firenze on 05/2000 Hellas and Turkey agreed in the methodology that would be followed in various fora for the construction of confidence meters. In the second category of these "Meters of intensity reduction", was included also the installation of direct channels of communication between chiefs of HCG and the Turkish Coast Guard Command (Koyloympis Th., Yfantis K., op.cit., note 10). According to the mentioned authors, SAR must be determined as common interest and is necessary this item to be discharged and demystified. The authors unfortunately they do not explain how this particular item can be discharged and demystified as also that it is a common item since it is connected with a large items of Hellenic - Turkish relations. Sometimes is necessary the authors beyond the theoretical background or their personal options to explain exactly how a lot of theories can become reality.

Note 60. It is marked that according to PRACTICAL of Hellenic Parliament (Period D- Session D') and more specifically the Permanent Committee of Production and Trade in the drawing of law of Ministry of Mercantile Marine "Ratification of convention on maritime SAR", the Convention of Hamburg was ratified after had preceded its Ratification from Turkey and the publication of the relative regulation according to its provisions.

Note 61. See Kladi - Eustathopoulou M., op.cit. pp. 171-172.

Note 62. See Kladi - Eystathopoulou M., op.cit., pp. 172-173.

Note 63. http://www.sgk.tsk.tr/baskanliklar/genel_sekreterlik/ingilizce/hist.asp

www.tsk.tr/10_ARSIV/10_1_Basin_Yayin_Faaliyetleri/10_2Basin_Duyurulari/2006/BD_24htm $\kappa \alpha l$ www .dzkk.tsk.tr/turkce/TĀTBIKAT̄LAR.php

See Karbounopoulos P., SFINA, on 20/02/2009, p. 12, titled "Exercise - challenge of Turks in Aegean", Meletis N., Ethnos tis Kyriakis, on 22-02-2009, p. 18, titled "With the look in the elections lose "battles" in Aegean", by him in the same newspaper on 08-03-2009, p. 12, titled "Hegemonic rehearsal of Ankara in Aegean". It is marked that in Etnos tis Kyriakis, on 09-09-2010, p. 20 in article of Meletis N., titled "Appointment for afterwards the elections gives the .... foreign policy", is recorded that "Mr. Ouzougkerin, in deed warned Hellas to avoid the unilateral actions and repeated the Turkish view that the all items are interrelated, as the length of territorial sea, FIR, SAR, exclusive economic zone”. See also Mpatrakoulis Th., Ethnos tis Kyriakis, on 21-02-2010, p. the 55, titled "Oil of Kastelorizo and the deficit strategic".

Note 64. www.ssm.gov.tr/TR/Projeler/demizaraclari/prjgrpharpgemisi/Pages/sgak_S.aspx.,and www.sgk.tsk.tr, and www.sgk.tsk.tr/baskanlikar/personel/sgk_yayinlari/25_yil_kitap_3parca/yarin.pdf. www.ulasimonline.com./ TSK_SGK/10015/RMK-Marinemin-hedefi-askeri-gemi-ihcari.htlm

Note 65. www.ssm.gov.tr/TR/Projeler/denizaraclari/prjgrpbot/Pages/90TONLUKSAHILGUVENLIK-BOTLA RI_S.aspx

See Minagias Ch., The geopolitical strategic and military force of Turkey, Touriki, Athens, 2010, p. 222 and next.

Note 66. Hellas in all the years in which have been assigned by the international organizations the co-ordination of air trafficking, the air SAR as well as the marine SAR has corresponded completely to its duties. 


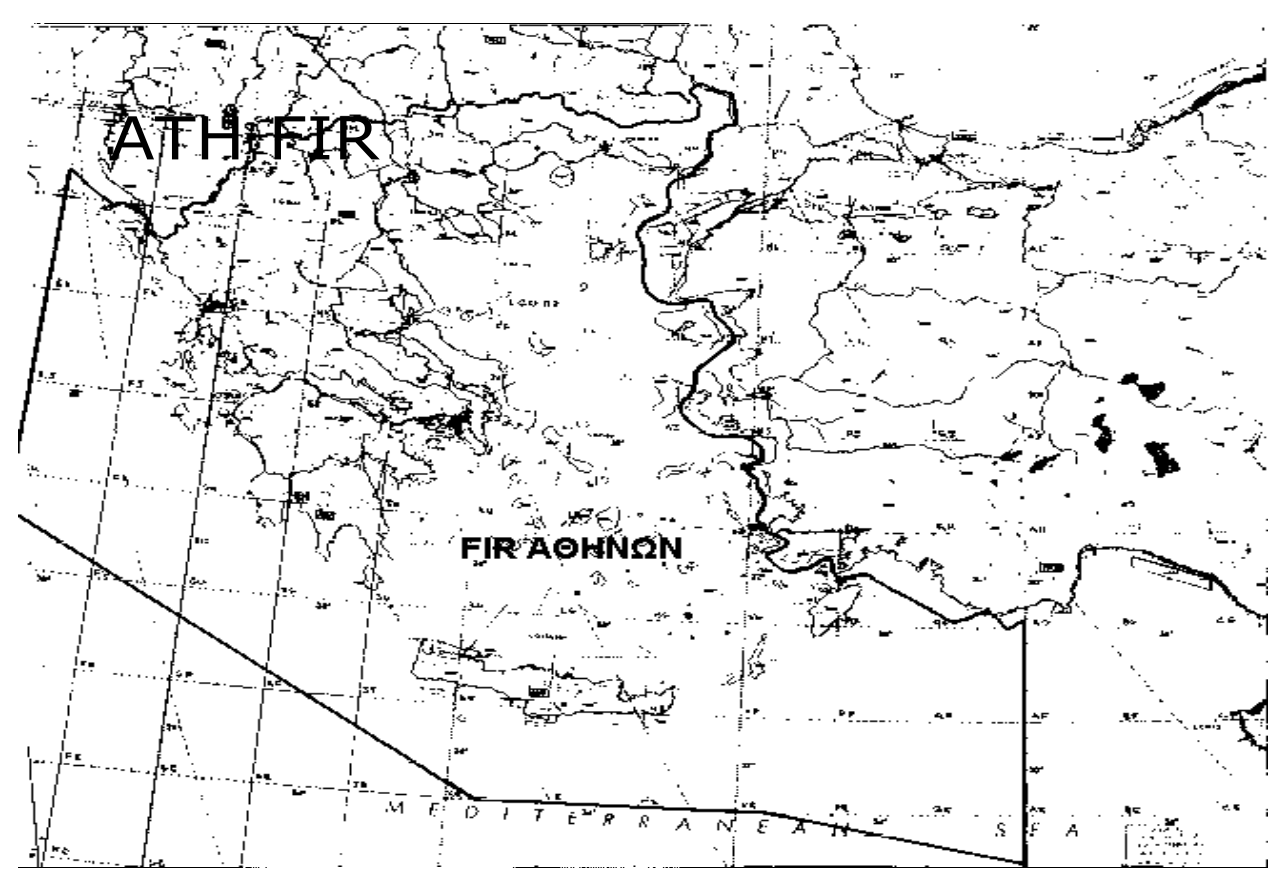

Figure 1. Competence Area of Athens FIR

Source: Ministry of Citizen Protection/HCG Headquarters/ SAR Division, 10/2010

\section{LRIT Configuration}

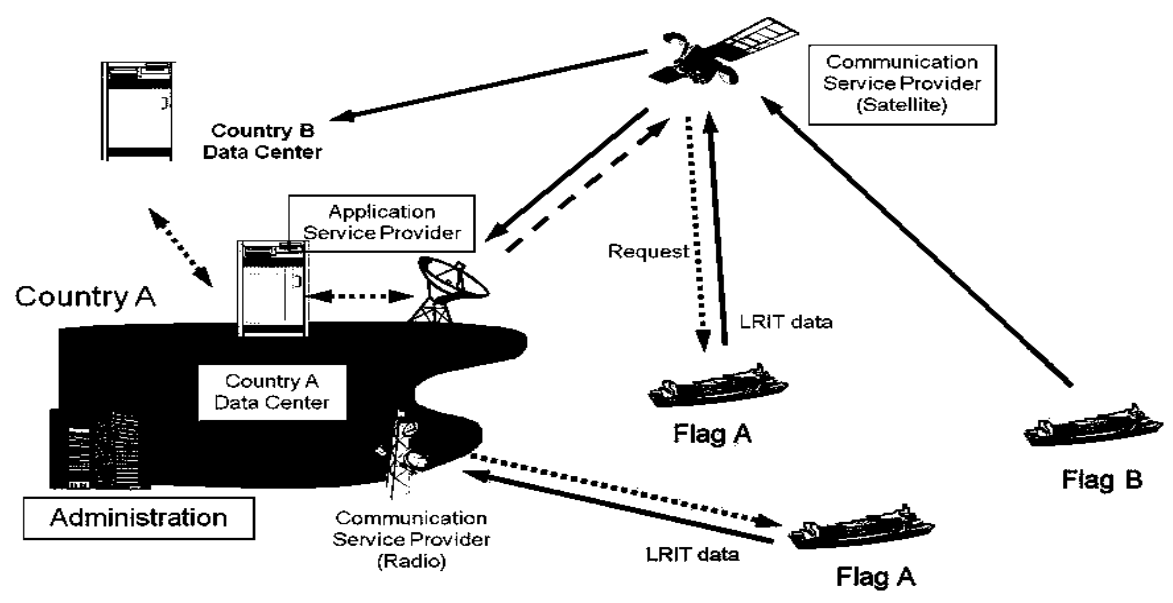

Figure 2. LRITConfiguration

Source: Ministry of Citizen Protection/HCG Headquartrs/ SAR Division, 10/2010 


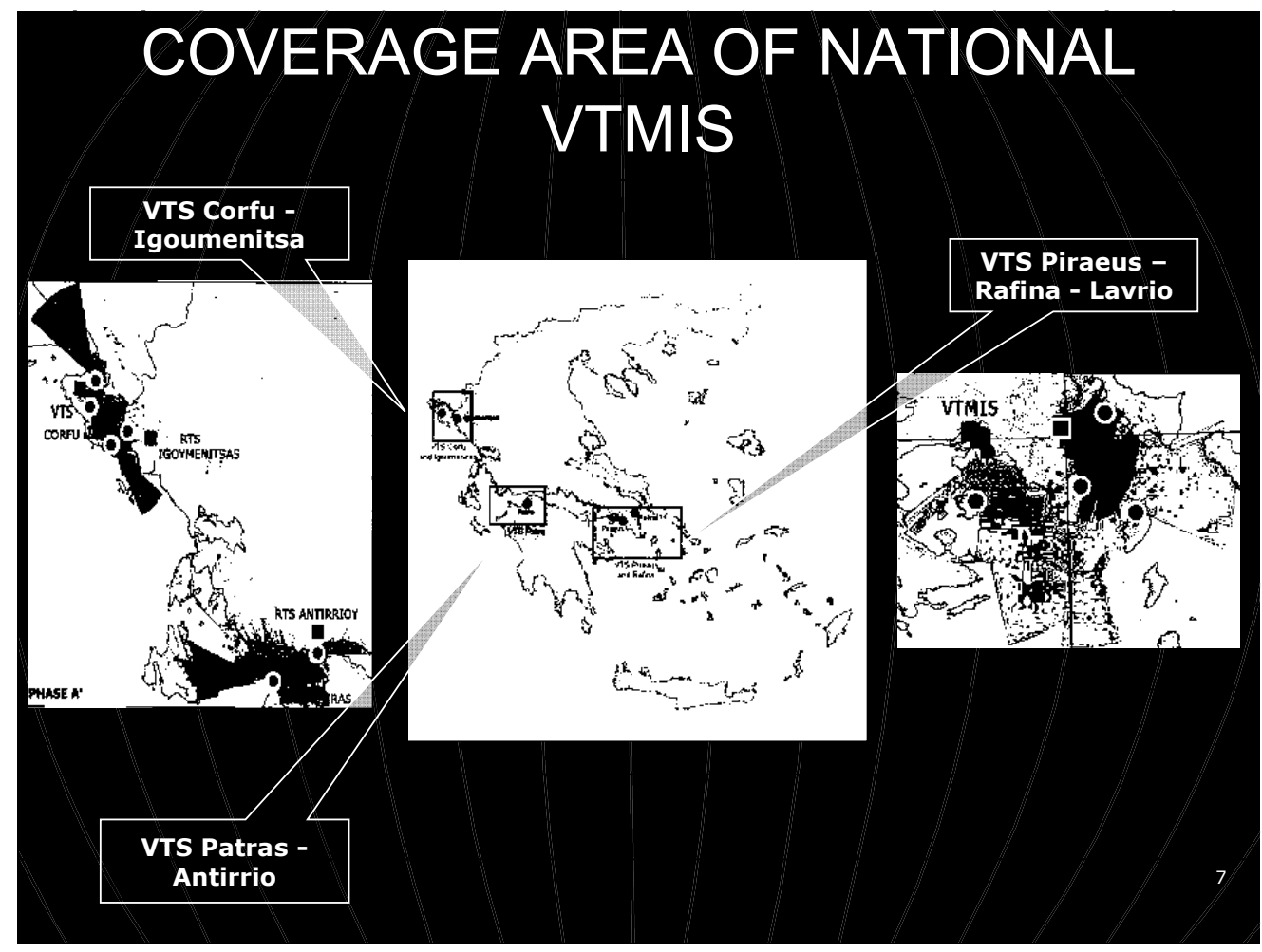

Figure 3. Coverage area of National VTMIS

Source: Ministry of Citizen Protection/HCG Headquarters/ SAR Division, 10/2010

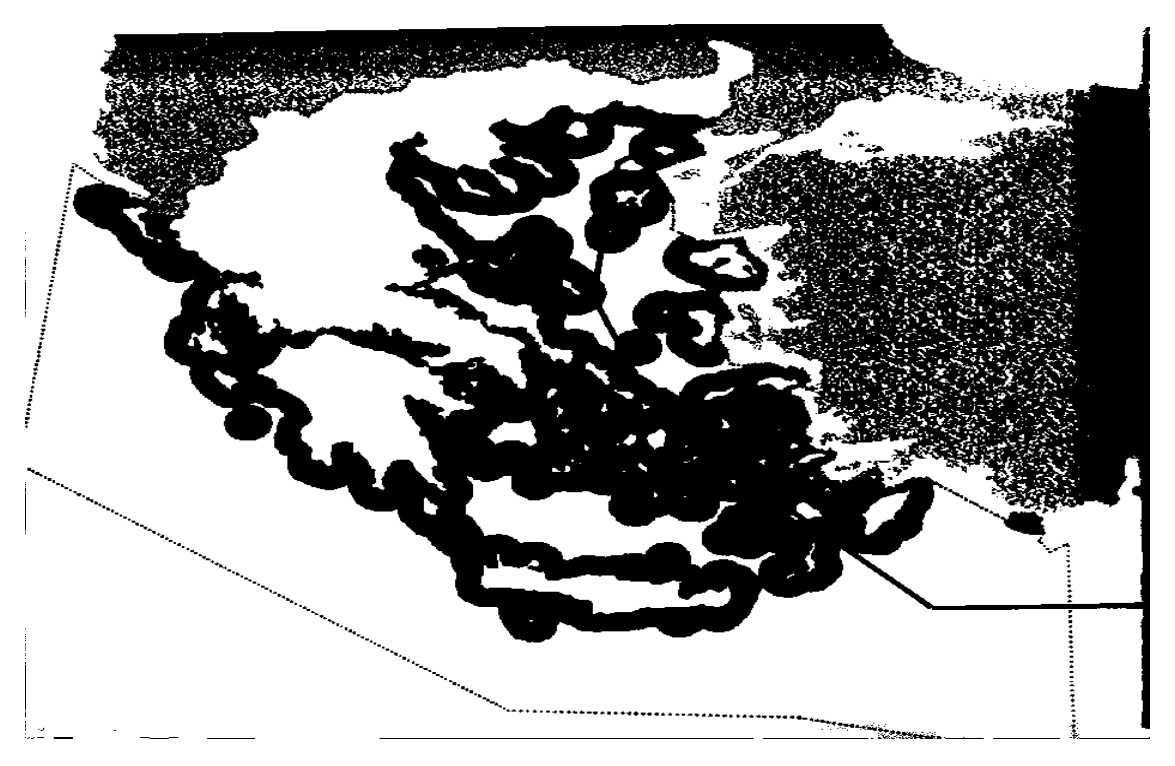




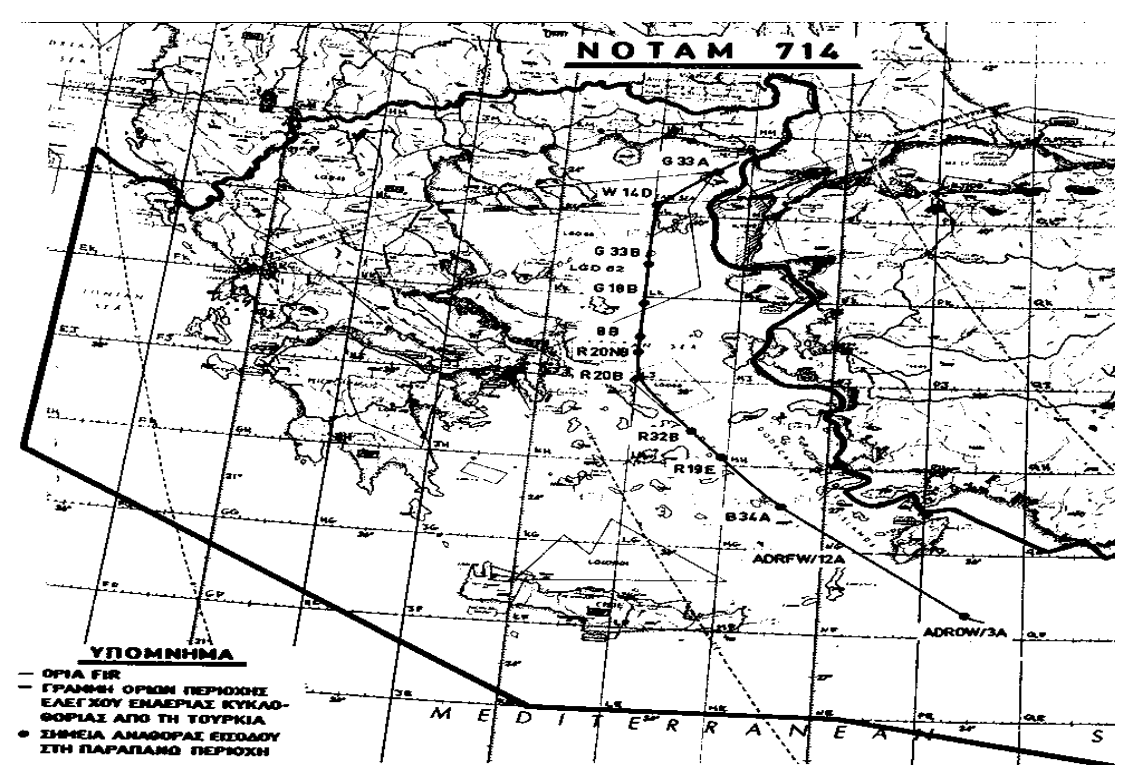

Figures 4. \& 5. NOTAM 714, airspace of $10 \mathrm{~nm}$, and the limits of FIR Athinai

Source: Hellenic National Defense Colleague, 06/2010

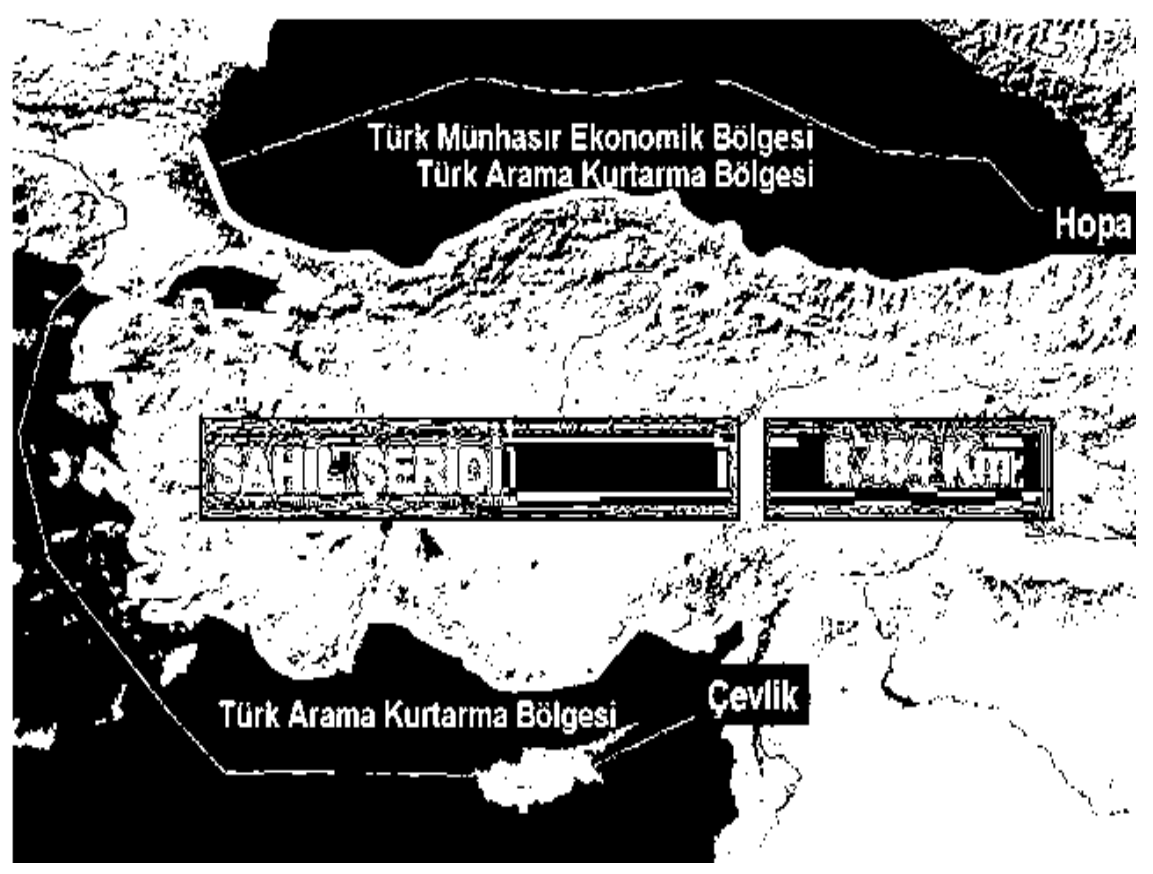

Figure 6. Area of SAR region according to Turkish Competent Authorities (TCGC)

Source: Annual Activities Report of 2009, Sahil Guvenlik Komutanligi 